\title{
Comparison of 2 systems of pasture allocation on milking intervals and total daily milk yield of dairy cows in a pasture-based automatic milking system
}

\author{
N. A. Lyons, ${ }^{1}$ K. L. Kerrisk, and S. C. Garcia \\ Dairy Science Group, Faculty of Veterinary Science, The University of Sydney, Camden (2570), NSW, Australia
}

\begin{abstract}
Cows milked in pasture-based automatic milking systems (AMS) have greater milking intervals than cows milked in indoor AMS. Long milking intervals greater than $16 \mathrm{~h}$ have a negative effect on milk yield and udder health. The impact of 2 systems of pasture allocation in AMS on milking interval and yield was investigated at the FutureDairy AMS research farm (Elizabeth Macarthur Agricultural Institute, New South Wales Department of Primary Industries, Camden, New South Wales, Australia) in late November to early December 2010. Two- (2WG) versus 3-way grazing (3WG) allocations per 24-h period were compared in a field study to test the hypothesis that an increase in the frequency of pasture allocation would reduce the milking interval and, therefore, increase milking frequency. The study involved the entire milking herd of 145 cows, with (mean $\pm \mathrm{SD}$ ) $\mathrm{DIM}=121 \pm 90 \mathrm{~d}$, 7-d average milking frequency $=1.52 \pm 0.41$ milkings $/$ cow per day, and 7 -d average milk yield $=21.3 \pm 7.6 \mathrm{~kg} / \mathrm{cow}$ per day. Cows were milked using 2 DeLaval VMS milking units (DeLaval International AB, Tumba, Sweden). Cows in the $3 \mathrm{WG}$ treatment had $31 \%$ reduced milking interval, $40 \%$ greater milking frequency, and $20 \%$ greater daily milk production compared with $2 \mathrm{WG}$. Increased milking frequency and milk production for $3 \mathrm{WG}$ was associated with greater utililization levels of the AMS milking units throughout the day. These results support the recommendation that, wherever possible, farmers installing AMS should incorporate sufficient infrastructure to accommodate $3 \mathrm{WG}$, which provides additional flexibility with managing extremely long (and short) milking intervals.
\end{abstract}

Key words: milking interval, feed allocation, automatic milking system, pasture based

\section{INTRODUCTION}

The introduction of automatic milking systems (AMS) in the early 1990s enhanced the possibility of

Received February 21, 2013.

Accepted April 3, 2013.

${ }^{1}$ Corresponding author: n.lyons@sydney.edu.au milking cows more frequently without significant extra labor input and consequently achieving higher milk yields (Garcia and Fulkerson, 2005; Stockdale, 2006). In 2001, the technology was introduced into pasturebased systems in a commercial installation in Victoria (Greenall et al., 2004) and with the establishment of the Greenfield Project in New Zealand (Jago et al., 2002). These were followed by the AMS research farm within the FutureDairy Project in Australia in 2006 (Garcia et al., 2007).

Under pasture-based conditions, milking frequency (MF; defined as the number of milking events/cow in any 24-h period), and daily milk yield (DY; defined as the kilograms of accumulated milk production of individual milking events in a 24 -h period) are usually lower than those reported in indoor housing systems (Garcia and Fulkerson, 2005). Moreover, milking intervals (MI; the interval between consecutive milking events, measured at every milking session in hours since the previous milking event) for pasture-based AMS dairy cows are higher and more variable than those housed indoors. In a historic data analysis from a pasture-based AMS, up to $30 \%$ of milking events occurred with intervals above $16 \mathrm{~h}$ (N. A. Lyons, unpublished data). These extended milking intervals have a negative effect on milk yield (Schmidt, 1960; Delamaire and Guinard-Flament, 2006) and udder health (Hammer et al., 2012). Yet, Rémond et al. (2009) found that cows could compensate for a long MI (over 17 or $19 \mathrm{~h}$ ), if the following milking occurred shortly after $(7$ or $5 \mathrm{~h}$, respectively). In that case, DY was not different from that in a conventional system with 2 milking events/d (11- to $13-\mathrm{h}$ or $10-$ to 14 -h MI, respectively). In the same study, cows with a very short and very long MI (3 and $21 \mathrm{~h}$ ) had an $11.5 \%$ reduced DY compared with those milked with an 11- and 13-h MI regimen. Therefore, it is likely that cows may not be flexible enough to accommodate for extremely long MI. In AMS, cows may have consecutive milking events with extended MI and, therefore, no opportunity for compensation would exist.

Increasing MF per cow by decreasing MI is an option for those systems aiming to increase the amount of milk collected per milking unit. Management strategies that increase cow traffic around the system are likely to 
have an effect on system performance and utilization. For the purpose of this study, cow traffic is defined as the visitation of cows to the dairy facility, either voluntarily or as a result of being fetched, which results in a milking event.

Previous studies under pasture-based conditions have addressed the effect of supplementary feeding (Jago et al., 2007); water availability and location (Jago et al., 2003); minimum MI (Jago et al., 2004); stage of lactation (Jago et al., 2006); and premilking teat preparation (Davis et al., 2008) on the general performance and throughput of AMS. Recognizing that feed is the main incentive for cows to move around the system in a voluntary and distributed manner (Prescott et al., 1998a,b), some initial reports have depicted the potential importance and effect of incentives put in place per day (Jago et al., 2004, 2007). Yet, to date, no research has been published that quantifies the actual effect of number of feed allocations on either animal or system performance in pasture-based systems. An increase in cow traffic has the potential to benefit cows in early lactation, which are in higher energy demand and more willing to move around the system compared with latelactation cows (Garcia and Fulkerson, 2005; Jago et al., 2006). Any reduction in MI, and associated increases in MF, needs to translate into a higher milk yield (per cow and per milking unit); otherwise, the general efficiency of the system would decline. It is also recognized that in some cases it may be more efficient to increase the number of cows milked rather than increase the number of milkings per cow (Woolford et al., 2004).

The aim of this study was to determine the effect of increasing the number of pasture allocations per day from 2 to 3 on the occurrence of extended MI $(>16 \mathrm{~h})$, MF, DY, and system performance. It was hypothesized that an increase in frequency of feed allocation would result in increased cow traffic, MF, and DY. Also greater system utilization (operating time and kilograms of milk collected per day) would be achieved.

\section{MATERIALS AND METHODS}

\section{General Farm Management and Description}

A pilot study was conducted between November 20 and December 8, 2010, at the FutureDairy AMS research farm (Elizabeth Macarthur Agricultural Institute, New South Wales Department of Primary Industries, Camden, New South Wales, Australia) to investigate the impact of 2 different grazing systems. The allocation of 2-way grazing (2WG) versus 3 -way grazing $(\mathbf{3} \mathbf{W G})$ per 24-h period was investigated. Ethics approval was granted through the Elizabeth Macarthur Agricultural
Institute Animal Ethics Committee (project number M10/12) before commencement of the project.

The herd had traditionally been operated under a 2WG system; however, cows had been exposed to $3 \mathrm{WG}$ before the commencement of this study. The study consisted of a 7-d adaptation period, during which cows were managed with $3 \mathrm{WG}$, followed by a 4 -d measurement period with $3 \mathrm{WG}$. At the conclusion of the 3WG treatment period, the pasture management was reverted back to the traditional $2 \mathrm{WG}$ treatment with a 3-d adaptation period and a 4-d measurement period. The trial could not be replicated as in a traditional crossover design because of limiting pasture availability and high cow numbers within the herd. Anecdotal observations conducted at the FutureDairy AMS research farm indicate that within $48 \mathrm{~h}$, naive heifers exposed to some training were trafficking around the farm system voluntarily (Kerrisk, 2009). Furthermore, traffic data during the measurement period in the study was stable, which suggests that a 7 -d adaptation was adequate as exposure to a new treatment.

The herd consisted of 145 cows (predominantly Holstein-Friesian and approximately 10 to $15 \%$ Illawarra breed), $30 \%$ primiparous and $70 \%$ multiparous. Before commencement of the study the herd had an average (mean $\pm \mathrm{SD}$ ) of $121 \pm 90$ DIM, 7-d average MF of 1.52 \pm 0.41 milking events/cow per day, and 7 -d average DY of $21.3 \pm 7.6 \mathrm{~kg}$ of milk/cow per day.

Each cow was fitted with an electronic identification transponder, which was necessary for passage through the automatic drafting gates (DeLaval Smart Selection Gate; DeLaval International AB, Tumba, Sweden) and for recognition at the milking stations. The transponder ensured that the details of all milking and trafficking events were recorded electronically by the herd management software (DeLaval VMS Client; DeLaval International $\mathrm{AB}$ ). Cows were milked through 2 single box milking units (DeLaval VMS; DeLaval International $\mathrm{AB}$ ) and milk yield recorded individually (DeLaval MM15; DeLaval International AB).

Pasture [predominantly a mix of Kikuyu (Pennisetum clandestinum) and ryegrass (Lolium perenne and Lolium multiflorum)] was allocated to cows based on a target intake of $18 \mathrm{~kg}$ of DM/d. In addition to pasture, cows were supplemented in the milking station with a set daily concentrate allowance of $6 \mathrm{~kg}$ of $\mathrm{DM} / \mathrm{d}$ (with a maximum daily carryover of 50\%) aimed to achieve an intake of $4 \mathrm{~kg}$ of DM/d (Dairy Elite Pellet, 16\% CP; Weston Milling Animal Nutrition, Enfield, Australia). Cows were offered their daily pasture allocation in equally sized portions according to the established treatments. In the $2 \mathrm{WG}$ treatment, cows were allocated $9 \mathrm{~kg}$ of DM/cow in each of 2 allocations, whereas during 
LYONS ET AL.

Table 1. Milking permission criteria for a herd milked in a pasture-based automatic milking system ${ }^{1}$

\begin{tabular}{lll}
\hline Item & DIM $\leq 70$ & DIM $>70$ \\
\hline Primiparous animals & $>4 \mathrm{~h}$ since last milking & $>8 \mathrm{~h}$ since last milking \\
Multiparous animals & Expected yield $>4 \mathrm{~kg} /$ milking & Expected yield $>4 \mathrm{~kg} /$ milking \\
& $>4 \mathrm{~h}$ since last milking & $>8 \mathrm{~h}$ since last milking \\
& Expected yield $>6.5 \mathrm{~kg} / \mathrm{milking}$ & Expected yield $>6.5 \mathrm{~kg} / \mathrm{milking}$ \\
\hline${ }^{1}$ Cows were granted access to the premilking waiting area if they met at least 1 of the criteria in the table.
\end{tabular}

the $3 \mathrm{WG}$ treatment, cows were allocated $6 \mathrm{~kg}$ of DM/ cow in each of the 3 pasture allocations. The distance from the dairy facility to each allocation was (mean \pm $\mathrm{SE}) 525 \pm 76 \mathrm{~m}$ for $2 \mathrm{WG}$ and $480 \pm 17 \mathrm{~m}$ for $3 \mathrm{WG}$. This meant that a cow that accessed each pasture allocation under $3 \mathrm{WG}$ would walk over $30 \%$ more per day compared with cows under 2WG.

Grazing management plans were developed weekly, using measured pasture cover as per normal farm practice. To allocate pasture, a minimum pasture allowance (total areal biomass, expressed as $\mathrm{kg}$ of $\mathrm{DM} / \mathrm{cow}$ ) of 35 $\mathrm{kg}$ of DM/cow per day was used (Bargo et al., 2003; Garcia and Holmes, 2005). This was achieved by aiming for pregrazing pasture cover allocations between 2,500 and $3,000 \mathrm{~kg}$ of $\mathrm{DM} / \mathrm{ha}$ and modifying allocation areas accordingly. Daily grazing areas were allocated using temporary electric fencing, with no back grazing permitted. Pregrazing pasture cover was measured within $24 \mathrm{~h}$ of the start of grazing, whereas postgrazing cover residual was measured within $24 \mathrm{~h}$ of the last cow exiting the paddock. Pasture cover was assessed daily during the study periods through indirect measurements of pasture height. The CDAX Pasture Meter (C-DAX Ltd., Palmerston North, New Zealand) height was used from d 1 to 7 and an electronic plate meter (Electronic Plate Counter; Farmworks Systems Ltd., Feilding, New Zealand) compressed pasture height thereafter. Both devices had similar accuracy (Lyons, 2007). Weekly calibration equations developed at the same experimental site (Garcia et al., 2008) were used for both devices to convert height into biomass. A correction factor (0.1489) was incorporated for the C-DAX Pasture Meter through calibration cuts done on site to validate the absolute difference between pre- and postgrazing pasture covers.

Any cow leaving the dairy after being milked, or refused access to the dairy (based on milking permission criteria; Table 1), would access each pasture allocation for a consistent period of time within treatment (active access hours $=24 \mathrm{~h} /$ number of allocations per 24-h period). In this manner, $2 \mathrm{WG}$ paddocks were set to have an active access time for each allocation of $12 \mathrm{~h}$, whereas in $3 \mathrm{WG}$, this was reduced to $8 \mathrm{~h}$. Under $2 \mathrm{WG}$, the allocations opened at 0800 and $2000 \mathrm{~h}$, whereas for
3WG, they opened at 0800 and $1600 \mathrm{~h}$ and at midnight. In addition to the active access time, cows had a period of time in which they were expected to voluntarily exit the allocation but during which no additional cows gained access to that allocation. Any cows that did not voluntarily exit a paddock were fetched and encouraged from the paddock to the dairy facility $2 \mathrm{~h}$ before the subsequent allocation closing for access. Thus, the maximum amount of time that any cow could spend in a given allocation (grazing strip) was $22 \mathrm{~h}$ for $2 \mathrm{WG}$ and $14 \mathrm{~h}$ for $3 \mathrm{WG}$. With these cow traffic management routines, the aim was to have the majority of cows accessing each pasture allocation.

As cows trafficked around the farm system they presented at automatic drafting gates and were either granted milking permission and drafted to the dairy, or denied milking permission and drafted to pasture. Milking permission was based on expected yield and minimum MI criteria as per Table 1 . In addition, milking permission was granted to any cow that had an incomplete milking from any individual quarter (less than $50 \%$ of expected milk yield) up to 2 consecutive times.

\section{Data Description}

Animal Data. Electronically captured data records included information on cow number, MI, and milk yield (MY; the sum of the 4 quarters, in kilograms of milk per cow per milking), as well as electronic drafting gate passing times, from which time spent in each area was calculated. Cow traffic variables for every milking event included return time (RT; time elapsed from exiting the dairy facility to the next time the cow presented itself back at the dairy facility when milking permission was granted, in $\mathrm{h}$ ), and premilking waiting area time (WT; time elapsed from entry to the premilking waiting yard to start of milking, in $\mathrm{h}$ ). The information per milking was then grouped and summed to generate daily data (24-h period between 0800 and $0759 \mathrm{~h}$ the following day). On a per-day basis, MI was represented by MF, and MY by DY. Manual records allowed identification of voluntary and forced milkings as a way to differentiate those traffic events that resulted 
from cows voluntarily walking to the dairy from those that resulted from cows being fetched from a stale pasture allocation, respectively.

Once in each treatment period, milk samples were collected from every milking event of every cow within a 24-h period for analysis of milk fat, milk protein, and SCC. Samples were analyzed for milk fat and milk protein concentrations using a Bentley B2000 infrared analyzer (Bentley, Chaska, MN) and SCC using a Bentley Somacount 500. Results were converted into a $24-\mathrm{h}$ equivalent production by taking MI into account to calculate an hourly MY and milk fat and milk protein rate. This was then extrapolated to a 24 -h period, assuming linearity of milk yield and composition (Davis et al., 2008). Somatic cell count was the arithmetic average of samples collected during each sampling period. Concentrate consumption (CC; amount of concentrates consumed in a 24-h period, in kilograms of DM per cow per $24 \mathrm{~h}$ ) in the milking station was electronically recorded per cow.

Pasture Data. Average daily pasture allowance and intake per cow were calculated using the pre- and postgrazing pasture covers, together with the area allocated and total milking herd size.

Milking Station Data. Data exported electronically allowed calculation of number of milking events, milk yield harvested, and operating time that each AMS unit performed per hour under both treatments. Data was then summarized per day to calculate total number of milking events, milk yield, and milking time per 24-h period.

\section{Statistical Analyses}

Outcome Variables. Four cow traffic-related outcomes were explored: RT, WT, MI, and MF. Seven outcomes were analyzed for cow performance: MY, DY and CC, milk fat and protein yield and content, as well as SCC. The likelihood of a cow having a voluntary milking and an extended MI was also analyzed at the cow level. At the herd level, postgrazing pasture cover and average pasture intake were the main variables of interest. System performance was evaluated by exploring the number of milking events and total daily milking time and yield (per hour and per 24-h period).

Predictor Variables. Treatment (2WG and $3 \mathrm{WG}$ ) and stage of lactation (SOL; early: $\leq 100$ DIM; mid: 101-200 DIM; late: $\geq 201$ DIM) were used for cow traffic and performance outcomes. Treatment was used for outcomes average postgrazing pasture cover and average intake per cow. Treatment and time of day in those cases that the hour information was required were used as for system performance outcomes.
Statistical Models. Descriptive analyses were conducted to understand the distribution of explanatory variables and their association with outcome variables. Data of MI are presented in a frequency distribution graph, with difference between treatments analyzed through a binomial test of proportions. All data were then analyzed using a multivariable linear mixed model, with parameter estimates calculated using residual maximum likelihood (REML).

The likelihood of occurrence of voluntary milkings and extended MI was analyzed as binary outcomes using generalized linear mixed models (GLMM), with results presented as odds ratios. An odds ratio is a ratio of odds of occurrence of an event in 2 groups. For example, the odds ratio of the number of pasture allocations for extended MI is the ratio of the odds of extended MI occurring in the $2 \mathrm{WG}$ group to the odds of them occurring in $3 \mathrm{WG}$ group.

The model for cow variates included treatment, SOL, and the interaction of treatment and SOL as fixed effects. Cow was included as a random effect. The model used to analyze average postgrazing pasture cover and average intake per cow included treatment as a fixed effect and day as a random effect. All the system performance models included treatment and time of day in those cases that the hour information was required as fixed effects. The AMS unit and day were included as random effects.

All analyses were conducted in the GenStat statistical package (13th edition; VSN International Ltd., Hemel Hempstead, UK). The assumptions of linearity, normality, and homoscedasticity were evaluated using residual diagnostics. The outcome was transformed if the assumption of normality or homoscedasticity was invalid (WT were square root transformed, and SCC were $\log$ transformed, but both the transformed and retransformed values are presented as outputs). Significant effects were determined if $P<0.05$.

\section{RESULTS}

\section{Cow Traffic}

The provision of 3 allocations of feed per day caused a reduction $(P<0.001)$ in RT and MI, as well as an increase $(P<0.001)$ in MF for a herd managed in a pasture-based AMS. No effect $(P=0.74)$ was observed of number of pasture allocations on WT (Table 2).

An interaction $(P<0.05)$ was observed between number of pasture allocations and SOL associated with changes in RT and WT. The decrease in RT under $3 \mathrm{WG}$ compared with $2 \mathrm{WG}$ was greater $(P<0.001)$ for latethan early- and mid-lactation cows. Only under $3 \mathrm{WG}$ early lactation cows had an hour longer $(P=0.005)$ 


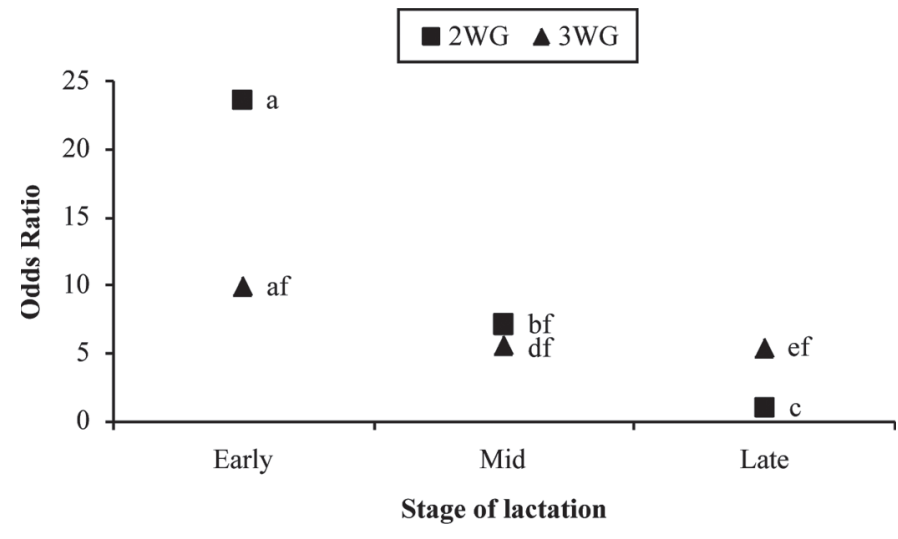

Figure 1. Odds ratios for cows in different stages of lactation (early: $\leq 100$ DIM; mid: 101-200 DIM; late: $\geq 201$ DIM), managed under 2 -way grazing $(2 \mathrm{WG} ; \boldsymbol{\square})$ and 3 -way grazing $(3 \mathrm{WG} ; \mathbf{\Delta})$ allocations per $24 \mathrm{~h}$, on the probability of having a milking occurring as a result of a cow voluntarily walking to the dairy facility. Different lowercase letters (a-f) indicate significant differences at $P<0.05$.

WT than mid- and late-lactation cows. An interaction $(P<0.05)$ between number of pasture allocations and SOL was found for MI and MF. In $2 \mathrm{WG}$, an increase in DIM was associated with greater $(P<0.001) \mathrm{MI}$ and reduced $(P=0.008) \mathrm{MF}$, whereas under $3 \mathrm{WG}$, cows in different SOL had similar MI and MF.

An interaction $(P<0.001)$ between number of pasture allocations and SOL was also found for voluntary cow traffic (Figure 1). An increase in DIM was associated with a decrease in voluntary cow traffic only for the $2 \mathrm{WG}$ treatment. Compared with $2 \mathrm{WG}$, cows in late lactation under $3 \mathrm{WG}$ were 5 times more likely to traffic voluntarily to the dairy facility.

Compared with $2 \mathrm{WG}$, cows in the $3 \mathrm{WG}$ treatment reduced the occurrence of milking events with intervals above $16 \mathrm{~h}$ from 64.4 to $27.0 \%$ and had a greater proportion of milking events occurring with intervals between 4 and $21 \mathrm{~h}$ (Figure 2). An interaction $(P<$ 0.001 ) between number of pasture allocations and SOL was found for likelihood of occurrence of extended MI (Figure 3). Cows were more likely to have a milking event with extended $\mathrm{MI}$ in $2 \mathrm{WG}$ than $3 \mathrm{WG}$, but the effect was much higher for cows in late than mid and early $\mathrm{SOL}(22,6$, and 3 times more likely to have an extended MI under 2WG than when under 3WG for early, mid, and late SOL, respectively).

\section{Milk Production, Composition, and Quality}

An interaction $(P=0.008)$ was observed between the number of pasture allocations and SOL for MY (Table 3 ). The provision of 3 versus 2 allocations of pasture was related to a decrease in MY for cows in mid and late lactation, whereas it did not affect early SOL cows.
Overall, the provision of an extra pasture allocation per day increased $(P<0.001)$ DY by almost $4 \mathrm{~kg}$ of milk/d.

Cows produced $22 \%$ more $(P<0.001)$ milk protein daily $(\mathrm{kg} / \mathrm{d})$ when managed with $3 \mathrm{WG}$ compared with 2WG. An interaction $(P<0.05)$ existed between the number of pasture allocations and SOL for milk fat yield $(\mathrm{kg} / \mathrm{d})$ and milk protein content (\%). Cows in mid and late lactation had increased $(P=0.019)$ milk fat yield $(\mathrm{kg} / \mathrm{d})$ only when managed under $3 \mathrm{WG}$ treatment. On the other hand, the early-lactation cows were the only ones to increase $(P=0.002)$ milk protein content $(\%)$ when under 3 WG. Cows had similar $(P>0.100)$ milk fat content (\%) and SCC when 2 or 3 pasture allocations were offered per day. The average individual cow SCC was 148,000 .

\section{Pasture and Concentrate Intake}

The average pregrazing pasture cover was $3,081 \mathrm{~kg}$ of DM/ha for $3 \mathrm{WG}$ and 2,624 kg of DM/ha for 2WG. Cows in both treatments had similar $(P>0.100)$ daily pasture allowance $(37.3 \pm 1.6 \mathrm{~kg}$ of $\mathrm{DM} /$ cow per day $)$, postgrazing pasture cover $(1,490 \pm 54 \mathrm{~kg}$ of $\mathrm{DM} / \mathrm{ha})$, and average daily pasture intake $(17.0 \pm 0.9 \mathrm{~kg}$ of $\mathrm{DM} / \mathrm{d}$ ). Daily pasture intake was evenly distributed throughout the allocations. Under $2 \mathrm{WG}$, cows consumed 42 and $50 \%$ of daily DMI in the 0800 and 2000 $\mathrm{h}$ allocations, respectively. Under $3 \mathrm{WG}$, cows consumed 34,33 , and $33 \%$ of daily DMI in the 0800,1600 , and $2000 \mathrm{~h}$ allocations, respectively.

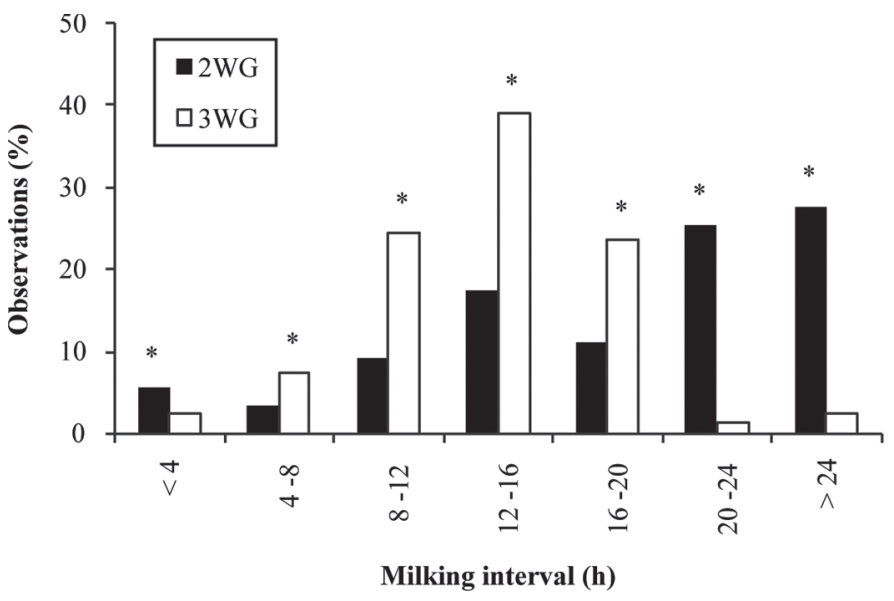

Figure 2. Frequency distribution of milking interval (h) resulting from 2-way grazing (2WG; 口) and 3-way grazing (3WG; $\square$ ) allocations per $24 \mathrm{~h}$. Significant $(P<0.05)$ treatment differences at each milking interval category are identified accordingly $(*)$. The time intervals below each bar correspond to the milking interval range (i.e., the bar at 4-8 relates to all milking events that had a milking interval between 4 and $8 \mathrm{~h}$ ). The categories $<4$ and $>24$ represent milking intervals smaller or greater than 4 and $24 \mathrm{~h}$, respectively. 
PASTURE ALLOCATION IN AUTOMATIC MILKING SYSTEMS
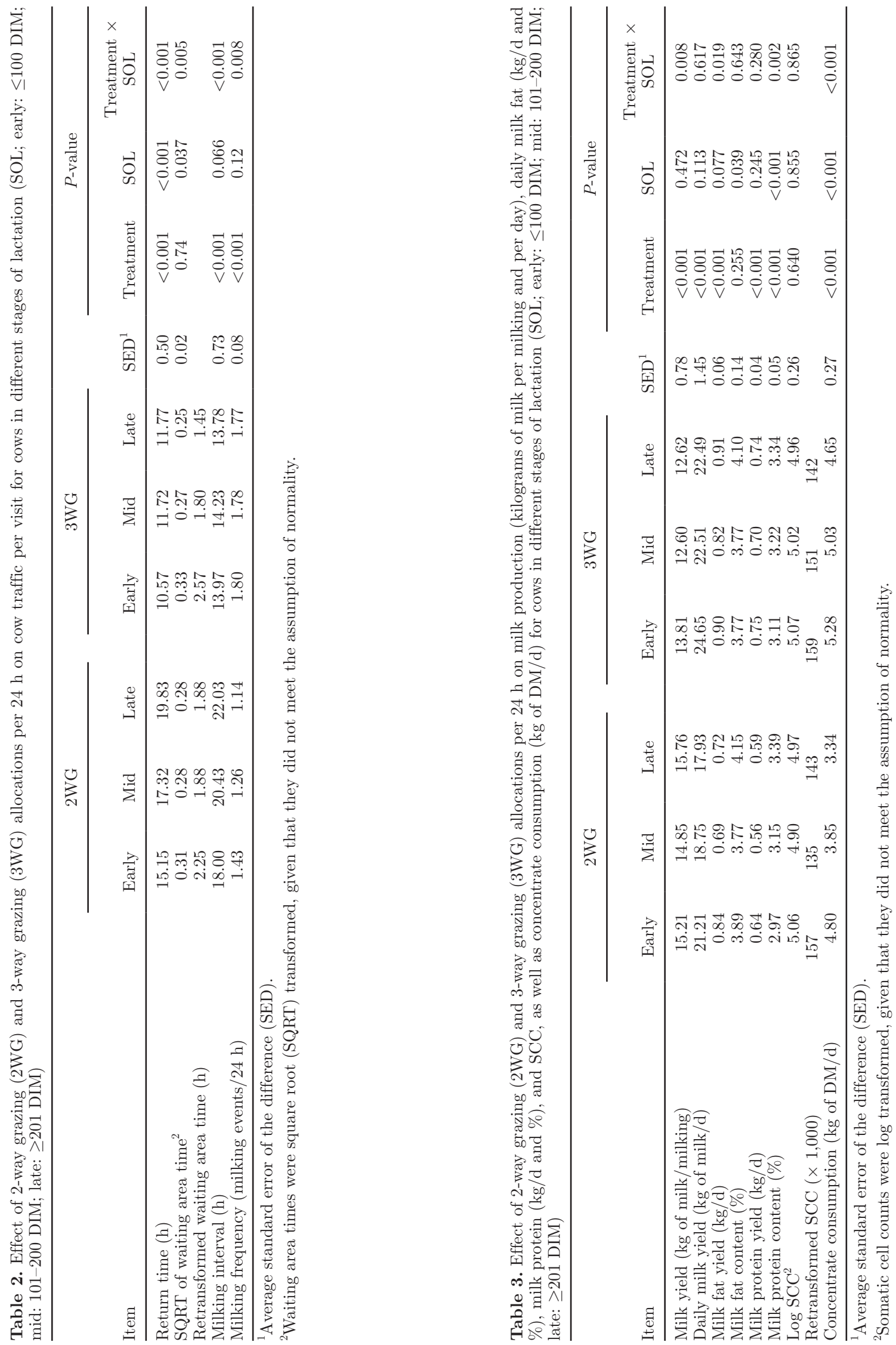
4500

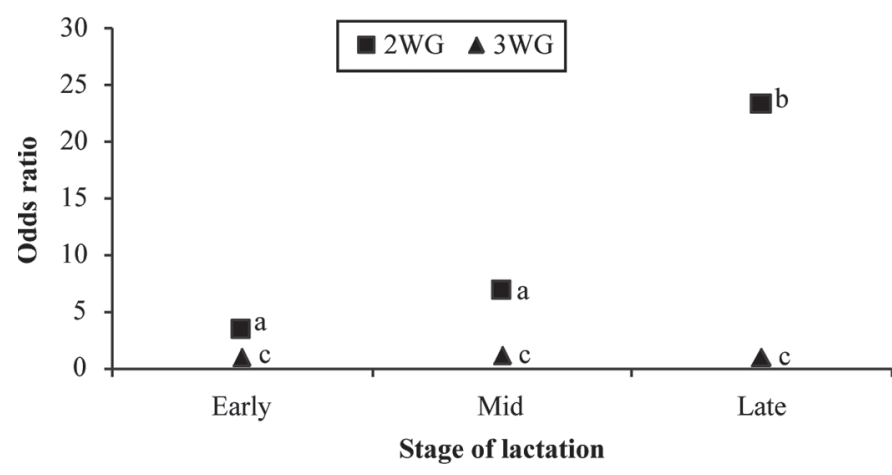

Figure 3. Odds ratios for cows in different stages of lactation (early: $\leq 100$ DIM; mid: 101-200 DIM; late: $\geq 201$ DIM), managed under 2 -way grazing $(2 \mathrm{WG} ; \mathbf{\square})$ and 3 -way grazing $(3 \mathrm{WG} ; \mathbf{\Delta})$ allocations per $24 \mathrm{~h}$, on the probability of having a milking event occurring with an extended interval $(>16 \mathrm{~h})$. Different lowercase letters $(\mathrm{a}-\mathrm{c})$ indicate significant differences at $P<0.05$.

An interaction $(P<0.001)$ was observed between number of pasture allocations and SOL for CC (Table $3)$. Only cows in mid and late lactation increased the $\mathrm{CC}$ by over $1 \mathrm{~kg}$ of DM/d when offered 3 allocations of pasture per day.

\section{System Performance}

The higher MF of cows in 3WG resulted in an increase in system performance and utilization (\% of time the AMS unit was used for milking related activities). Compared with $2 \mathrm{WG}$, during $3 \mathrm{WG}$, each robot performed more $(P<0.001)$ milkings per day, collected more $(P=0.011)$ milk per day, and operated more $(P$ $=0.002$ ) hours per day (Table 4 ).

The provision of an extra feed allocation per day was associated with more milking sessions per hour, as well as a more even distribution of milking events throughout the day (Figure 4). An interaction $(P<$ 0.001) existed between the number of pasture allocations and time of the day. A higher number of milkings per hour were performed under $3 \mathrm{WG}$ between 0100 and $0200 \mathrm{~h}$, between 1000 and $1100 \mathrm{~h}$, between 1200 and $1300 \mathrm{~h}$, and between 1500 and $1800 \mathrm{~h}$. The number of milkings per hour was similar between treatments for other times.

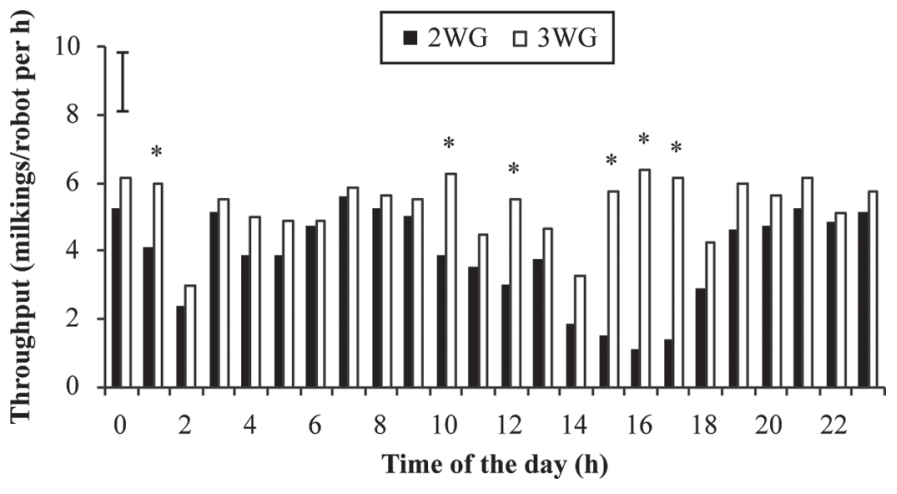

Figure 4. Effect of 2-way grazing (2WG; ) and 3 -way grazing (3WG; $\square$ ) allocations per $24 \mathrm{~h}$ on system throughput (milkings/automatic milking system per hour). The time below each bar corresponds to the milkings that occurred in that hour (i.e., the bar at 16 relates to all milkings between 1600 and $1700 \mathrm{~h}$ ). The vertical bar indicates average standard error of the difference. Categories with significantly different throughput $(P<0.05)$ are identified accordingly $\left(^{*}\right)$.

\section{DISCUSSION}

The aim of this study was to compare 2 systems of pasture allocation on cow traffic, milk production, and system utilization in a pasture-based AMS. This study has shown that offering pasture-based AMS cows with 3 pasture allocations per day, instead of 2 , was related to a reduction in $\mathrm{MI}$, an increase in $\mathrm{MF}$, and an increase in DY, together with a greater system utilization.

As feed is the main incentive encouraging cows to move around a system (Prescott et al., 1998a,b), in the current study, increasing the number of pasture allocations in a day reduced MI by reducing RT. This is in agreement with previous reports (Rodenburg and Wheeler, 2002; Jago et al., 2004; Jago et al., 2007) that increasing the frequency of incentive allocation was a possible way to increase cow traffic in an AMS. The reduction in average $\mathrm{RT}$ from $2 \mathrm{WG}$ to $3 \mathrm{WG}$, which ranged from $4.5 \mathrm{~h}$ (early-lactation cows) to $8 \mathrm{~h}$ (latelactation cows), could be explained by 2 key factors. First, there was a reduction in the amount of feed made available under $3 \mathrm{WG}$ (in total $\mathrm{kg}$ of $\mathrm{DM}$ /allocation), which created the potential for feed depletion to occur more rapidly, thereby creating an incentive for cows to exit the allocation sooner in search of additional

Table 4. Effect of 2-way grazing (2WG) and 3-way grazing (3WG) on predicted mean system performance indicators

\begin{tabular}{lcccr}
\hline Item $^{1}$ & $2 \mathrm{WG}$ & $3 \mathrm{WG}$ & SED $^{2}$ & $P$-value \\
\hline Milkings (milking events/AMS per day) & 93 & 128 & 5 & $<0.001$ \\
Total yield (kg of milk/AMS per day) & 1,394 & 1,680 & 97 & 0.011 \\
Milking time (h/AMS per day) & 15.07 & 17.30 & 0.57 & 0.002 \\
Idle time per AMS (\% of day) & 22.2 & 13.9 & 1.8 & $<0.001$ \\
\hline
\end{tabular}

${ }^{1} \mathrm{AMS}=$ automatic milking system.

${ }^{2}$ Standard error of the difference. 
feed. Second, the maximum amount of time cows could spend in one allocation was reduced under $3 \mathrm{WG}(22 \mathrm{~h}$ for $2 \mathrm{WG}$ vs. $14 \mathrm{~h}$ for $3 \mathrm{WG}$ ). This was associated with a reduced active access period to each allocation and a reduced voluntary exiting period (before fetching), both of which likely affected mean RT. However, voluntary milkings were similar across treatments (cows trafficking to the dairy without human encouragement) for cows in early and mid SOL. Moreover, cows in late lactation increased their voluntary movement when managed with $3 \mathrm{WG}$. When only the voluntary milkings were considered, the cows in $3 \mathrm{WG}$ still had a reduction of almost $2 \mathrm{~h}$ in RT (data not shown here).

In this study, the AMS units were operating at a high cow:robot ratio (72 cows/AMS unit) and performed between 4 and 5 milkings/h. Previous work found that, on average, single box milking units can perform 6 to 8 milkings/h (de Koning and Ouweltjes, 2000). In the current study, greater average MI caused an increase in the time each cow spent in the milking crate and, therefore, reduced robot throughput. Average WT of $2 \mathrm{~h}$ in this study suggests that robot throughput could have been a limiting factor. However, it should be noted that time spent in the premilking waiting area is not an absolute measure of the size of the queue (rather an indication), because an individual cow can spend an extended period of time in the premilking waiting yard even if the units are available for milking. Under $2 \mathrm{WG}$, a higher proportion of late-lactation cows were being fetched from the paddock; therefore, a larger number of cows entered the premilking waiting yard over a short period. This, combined with an expected reduction in their motivation to move around the system (Jago et al., 2006), caused a higher WT. A study conducted in an indoor AMS comparing the provision of forage 2 versus 6 times per day found that at a higher frequency of feeding, the WT was significantly shorter (Oostra et al., 2005). However, in that study, there were less than 5 cows in the premilking waiting yard, and waiting area times were below $20 \mathrm{~min}$, which suggested that cows might have had an ability to anticipate the queue at the milking unit. This is generally not possible for cows grazing at pasture because they are not positioned to have a clear view of the premilking waiting yard from the paddock.

A reduction in RT could decrease MI. Yet, increasing the number of pasture allocations per day had a greater effect over RT than over MI, which is likely to be explained by WT limiting the potential reduction in MI in the current study. Therefore, WT should also be considered in future research if the benefits of improved cow traffic around the farm system are to be capitalized.
Despite 3WG having a lower average MI than 2WG, there was still a wide range in the frequency distribution of MI of cows in pasture-based AMS. The average $\mathrm{MI}$ and the proportion of milking events occurring with extended intervals (above $16 \mathrm{~h}$ ) under 3WG had similar values to those found by FutureDairy for a herd managed under a 2WG system (around 30\%; N. A. Lyons, unpublished data). It remains to be seen if treatment differences would be maintained if the baseline parameters of $2 \mathrm{WG}$ had been higher.

The higher MF of cows in 3WG was directly related to their lower MI and explains the higher CC and DY. Given that feed is available to the cow at every milking event, an increase in MF is commonly associated with an increase in CC. As cows under 3WG consumed the same average amount of pasture per day but increased CC compared with $2 \mathrm{WG}$, it is likely that a higher DMI could have driven a higher DY (Bargo et al., 2003). An increase in MF drives an increase in DY (Stockdale, 2006), possibly due to more frequent removal of proteins such as serotonin (Collier et al., 2012) or a factor of inhibition of lactation (Wilde et al., 1995), which could be responsible for having a negative effect on lactation. Similar MF to those obtained here under 3WG where reported by Jago and Burke (2010) for a high-input pasture-based AMS managed with 3 allocations of pasture per day and $18 \%$ of diet coming from non-home-grown feed.

Adjusting milk composition variables to the preceding MI was previously suggested as an effective way to account for the variability that can occur in cows milked in an AMS (Friggens and Rasmussen, 2001; Løvendahl and Chagunda, 2011). Previous research conducted by Speicher et al. (1994) showed that an increase in MF (from 2 to 3 times per day) was associated with a decrease in milk protein content (\%) for primiparous and multiparous cows and a decrease in milk fat content (\%) only in multiparous cows. Similarly, in a review by Davis et al. (1999), once-per-day milking was related to greater milk fat and protein content compared with the traditional 2 milkings per day. Clark et al. (2006) reported an increase in annual fat and protein yield but a decrease in annual fat and protein content for cows milked twice per day compared with those milked once per day. Although the effect was not significant in the present study, cows under 3WG had lower milk fat content (\%). This effect had been reported previously (Løvendahl and Chagunda, 2011) and can relate to a dilution effect of the associated greater DY of those cows. Moreover, MI has an effect on the proportion of alveolar and cisternal milk, which in turn affects the fat content proportionally more than the protein content (Ayadi et al., 2004). Greater MF has also been related 
to lower SCC (Dahl et al., 2004), although due to the short duration of the current study, the lack of change in SCC was not entirely unexpected. However, the current study confirms that acceptable SCC concentrations can be achieved with AMS (a SCC below 200,000 is required to avoid penalties; Dairy Farmers Milk Cooperative Milk Policy 2012-2013, Australia), which had been questioned in the past (de Koning, 2011).

The lack of significant difference in daily mean pasture allowance and intake was expected, as the same grazing management rules were imposed for both treatments. This is also indicative of correct implementation of treatments. In conventional milking systems, an increase in feeding frequency has been related to an increase in time spent feeding but with no difference in total DMI (DeVries et al., 2005). Another study comparing 1 with 6 allocations of feed per day for earlylactation cows (Dalley et al., 2001), showed a change in grazing pattern during the day, but no difference in total grazing time and no change in herbage intake or milk yield between the allocation treatments. In agreement with those reports, in the current study, a higher frequency of feed allocation resulted in no difference in average daily pasture disappearance. The increase in CC was more likely to be attributed to the more frequent visitation to the milking unit. Although cows in both treatments had a similar daily pasture allowance, the average pregrazing pasture cover for $3 \mathrm{WG}$ was higher than for $2 \mathrm{WG}$. It is possible that this could have affected intake due to a positive effect of pasture cover on bite mass (Rook et al., 1994), as normally substitution effects (rather than additive effects) would have been expected (Bargo et al., 2003). Yet, conclusions about intakes and assumptions on feed conversion efficiency should be made with caution, given that pasture intake was calculated by the difference between pre- and postgrazing pasture covers using a measuring device that has an associated measuring error.

The increase in system utilization with the $3 \mathrm{WG}$ treatment was predominantly caused by an increase in the number of milking events and the resultant increase in milk yield collected per day. Those factors have been previously reported to affect milking unit utilization (Davis et al., 2005). Contrary to previous findings (Jago et al., 2002), the throughput through the early hours of the mornings was not significantly reduced in either treatment. The low-throughput levels between 0200 and $0300 \mathrm{~h}$, and between 1400 and $1500 \mathrm{~h}$ were due to automated system washes being conducted during these hours. Peak throughput times coincided with the timing of fresh pasture allocations being made available.

The current design of this study was the best possible, given the current limitations of pasture availability and herd size. Yet, it the risk of confounding treatment and period effects must be acknowledged. Furthermore, ideally, 3WG is best practiced with 3 laneways leading out from the dairy that allow cows to be sent in 3 directions over a 24 -h period. The site at which this study was conducted only had 2 laneways leading out form the dairy, which meant that cows had to be fetched from the first allocation of the day before the start of the active access period of the third allocation, as each alternate allocation shared the same laneway. This meant that it was essential for fetching to be conducted at around 14 $\mathrm{h}$ after the allocation was opened. If the voluntary exiting period could be extended (commonly up to about $20 \mathrm{~h}$ ), a greater proportion of voluntary milkings would be expected. Also, a relatively lower performance level was observed under the $2 \mathrm{WG}$ treatment, as higher MF can be achieved with $2 \mathrm{WG}$. Whether or not the same proportional impact of $3 \mathrm{WG}$ would have been observed had the initial MF of the $2 \mathrm{WG}$ been more typical (i.e., $>1.5$ milking events/d), remains to be investigated. Understanding the impact of 2 compared with 3 pasture allocations per day is crucial to ensure that farmers are informed if they make a decision to incorporate AMS into a farm layout that is limited to $2 \mathrm{WG}$. Additionally, special circumstances may create a need or desire for farmers to reduce the number of pasture allocation from 3 to 2. Such circumstances may arise during periods of heavy supplementary feeding or during times when the location of grazable forages are not spread across the 3 designated farm areas. It is unlikely that an increase beyond 3 allocations per day could result in a worthwhile increase in cow traffic because the reduction in active access time would limit the proportion of cows that gain access to the allocation, and cow time budget constraints could start limiting traffic.

\section{CONCLUSIONS}

The provision of 3 allocations of pasture per day increased cow traffic, reduced MI, and increased DY of cows in a pasture-based AMS compared with offering 2 allocations per day. This makes the management put in place particularly attractive because it would not only increase the MF and DY in early-lactation cows, but also in late-lactation cows that are notoriously more difficult to motivate. Overall, the $3 \mathrm{WG}$ treatment was associated with higher utilization of the system and consequentially higher yields of milk collected per AMS unit. The benefits under 3WG seem to justify the time spent conducting an extra daily fetching. These results support the traditional recommendation that farmers should use $3 \mathrm{WG}$, as it has significant benefits for pasture-based AMS. Thus, significant value exists for farmers to consider the potential for $3 \mathrm{WG}$ when they 
are designing or modifying their farm layout for the incorporation of AMS.

\section{ACKNOWLEDGMENTS}

The authors thank the investors of FutureDairy (a national industry-driven project); Dairy Australia (Melbourne, Australia), NSW Department of Primary Industries (Orange, Australia), DeLaval International AB (Tumba, Sweden), and The University of Sydney (Sydney, Australia); and the Dairy Research Foundation (Camden, Australia) for their support. We also thank the farm staff (Terry Osborne from NSW Department of Primary Industries, and Shannon Bennetts, Daniel Dickeson, and Grant Oldfield from The University of Sydney) and Rene Kolbach (The University of Sydney) for their assistance in preparing and running the study. The authors also appreciate the critical revision of this manuscript by Cameron Clark (The University of Sydney).

\section{REFERENCES}

Ayadi, M., G. Caja, X. Such, M. Rovai, and E. Albanell. 2004. Effect of different milking intervals on the composition of cisternal and alveolar milk in dairy cows. J. Dairy Res. 71:304-310.

Bargo, F., L. D. Muller, E. S. Kolver, and J. E. Delahoy. 2003. Production and digestion of supplemented dairy cows on pasture. J. Dairy Sci. 86:1-42.

Clark, D. A., C. V. C. Phyn, M. J. Tong, S. J. Collis, and D. E. Dalley. 2006. A systems comparison of once- versus twice-daily milking of pastured dairy cows. J. Dairy Sci. 89:1854-1862.

Collier, R. J., L. L. Hernandez, and N. D. Horseman. 2012. Serotonin as a homeostatic regulator of lactation. Domest. Anim. Endocrinol. 43:161-170.

Dahl, G. E., R. L. Wallace, R. D. Shanks, and D. Lueking. 2004. Hot topic: Effects of frequent milking in early lactation on milk yield and udder health. J. Dairy Sci. 87:882-885.

Dalley, D. E., J. R. Roche, P. J. Moate, and C. Grainger. 2001. More frequent allocation of herbage does not improve the milk production of dairy cows in early lactation. Aust. J. Exp. Agric. 41:593599.

Davis, K. L., W. J. Fulkerson, S. C. Garcia, D. Dickeson, and I. M. Barchia. 2008. Premilking teat preparation for Australian pasturebased cows milked by an automated milking system. J. Dairy Sci. 91:2604-2609.

Davis, K. L., J. G. Jago, R. Wieliczko, P. J. A. Copeman, K. Bright, and M. W. Woolford. 2005. Factors influencing milk harvesting efficiency in an automatic milking system. Pages 271-275 in Proc. New Zealand Soc. Anim. Prod., Christchurch, New Zealand. New Zealand Society of Animal Production Inc., Hamilton, New Zealand.

Davis, S. R., V. C. Farr, and K. Stelwagen. 1999. Regulation of yield loss and milk composition during once-daily milking: A review. Livest. Prod. Sci. 59:77-94.

de Koning, K. 2011. Automatic milking: Common practice on over 10,000 dairy farms worldwide. Pages 14-31 in Dairy Research Foundation Symposium 2011, The University of Sydney, Camden, Australia, Camden, NSW, Australia. University Printing Services Sydney, Sydney, Australia.

de Koning, K., and W. Ouweltjes. 2000. Maximising the milking capacity of an automatic milking system. Pages $38-46$ in Robotic Milking: Proceedings of the International Symposium Held in Lelystad, the Netherlands. Wageningen Pers, Wageningen, the Netherlands.
Delamaire, E., and J. Guinard-Flament. 2006. Increasing milking intervals decreases the mammary blood flow and mammary uptake of nutrients in dairy cows. J. Dairy Sci. 89:3439-3446.

DeVries, T. J., M. A. G. von Keyserlingk, and K. A. Beauchemin. 2005. Frequency of feed delivery affects the behavior of lactating dairy cows. J. Dairy Sci. 88:3553-3562.

Friggens, N. C., and M. D. Rasmussen. 2001. Milk quality assessment in automatic milking systems: Accounting for the effects of variable intervals between milkings on milk composition. Livest. Prod. Sci. 73:45-54

Garcia, S. C., and W. J. Fulkerson. 2005. Opportunities for future Australian dairy systems: A review. Aust. J. Exp. Agric. 45:10411055.

Garcia, S. C., W. J. Fulkerson, and S. U. Brookes. 2008. Dry matter production, nutritive value and efficiency of nutrient utilization of a complementary forage rotation compared to a grass pasture system. Grass Forage Sci. 63:284-300.

Garcia, S. C., W. J. Fulkerson, R. Nettle, S. Kenny, and D. Armstrong. 2007. FutureDairy: A national, multidisciplinary project to assist dairy farmers to manage future challenges-Methods and early findings. Aust. J. Exp. Agric. 47:1025-1031.

Garcia, S. C., and C. W. Holmes. 2005. Seasonality of calving in pasture-based dairy systems: Its effects on herbage production, utilization and dry matter intake. Aust. J. Exp. Agric. 45:1-9.

Greenall, R. K., E. Warren, and M. Warren. 2004. Integrating automatic milking installations (AMIs) into grazing systems - Lessons from Australia. Pages 273-279 in conf. proc. Automatic Milking: A Better Understanding, Lelystad, the Netherlands. Wageningen Academic Publishers, Wageningen, the Netherlands.

Hammer, J. F., J. M. Morton, and K. L. Kerrisk. 2012. Quarter-milking-, quarter-, udder- and lactation-level risk factors and indicators for clinical mastitis during lactation in pasture-fed dairy cows managed in an automatic milking system. Aust. Vet. J. 90:167-174.

Jago, J., K. Bright, P. Copeman, K. Davis, A. Jackson, I. Ohnstad, R. Wieliczko, and M. Woolford. 2004. Remote automatic selection of cows for milking in a pasture-based automatic milking system. Pages 241-245 in Proc. New Zealand Soc. Anim. Prod., Hamilton, New Zealand. New Zealand Society of Animal Production, Hamilton, New Zealand.

Jago, J., and J. Burke. 2010. An evaluation of two pastoral dairy production systems using automatic milking technology. Pages 109-116 in Proc. New Zealand Grassland Assoc., Christchurch, New Zealand. New Zealand Grassland Association, Wellington, New Zealand.

Jago, J., P. Copeman, K. Bright, D. McLean, I. Ohnstad, and M. Woolford. 2002. An innovative farm system combining automated milking with grazing. Pages 115-119 in Proc. New Zealand Soc. Anim. Prod., Palmerston North, New Zealand. New Zealand Society of Animal Production, Hamilton, New Zealand.

Jago, J., A. Jackson, and M. Woolford. 2003. Dominance effects on the time budget and milking behaviour of cows managed on pasture and milked in an automated milking system. Pages 120-123 in Proc. New Zealand Soc. Anim. Prod., Queenstown, New Zealand. New Zealand Society of Animal Production, Hamilton, New Zealand.

Jago, J. G., K. L. Davis, P. J. Copeman, I. Ohnstad, and M. M. Woolford. 2007. Supplementary feeding at milking and minimum milking interval effects on cow traffic and milking performance in a pasture-based automatic milking system. J. Dairy Res. 74:492499.

Jago, J. G., K. L. Davis, and M. W. Woolford. 2006. Stage of lactation affects the milking performance and behaviour of cows in a pasture-based automated milking system. Pages 258-262 in Proc. New Zealand Soc. Anim. Prod., Napier, New Zealand. New Zealand Society of Animal Production Inc., Hamilton, New Zealand.

Kerrisk, K. 2009. Management Guidelines for Pasture-Based AMS Farms 2010. Dairy Australia, Australia, Southbank, Victoria, Australia.

Løvendahl, P., and M. G. G. Chagunda. 2011. Covariance among milking frequency, milk yield, and milk composition from automatically milked cows. J. Dairy Sci. 94:5381-5392. 
Lyons, N. 2007. Calibración de un nuevo método de estimación indirecta de disponibilidad forrajera en pasturas típicas de Australia. Ingeniero Agronomo, Facultad de Agronomia, Universidad de Buenos Aires, Argentina.

Oostra, H. H., J. Stefanowska, and K. Sällvik. 2005. The effects of feeding frequency on waiting time, milking frequency, cubicle and feeding fence utilization for cows in an automatic milking system. Acta Agric. Scand. Section A Anim. Sci. 55:158-165.

Prescott, N. B., T. T. Mottram, and A. J. F. Webster. 1998a. Effect of food type and location on the attendance to an automatic milking system by dairy cows and the effect of feeding during milking on their behaviour and milking characteristics. Anim. Sci. 67:183-193.

Prescott, N. B., T. T. Mottram, and A. J. F. Webster. 1998b. Relative motivations of dairy cows to be milked or fed in a Y-maze and an automatic milking system. Appl. Anim. Behav. Sci. 57:23-33.

Rémond, B., D. Pomiès, C. Julien, and J. Guinard-Flament. 2009. Performance of dairy cows milked twice daily at contrasting intervals. Animal 3:1463-1471.

Rodenburg, J., and B. Wheeler. 2002. Strategies for incorporating robotic milking into North American herd management. Pages III18-III-32 in Proc. The First North American Conference on Robotic Milking, Toronto, Canada. Wageningen Pers, Wageningen, the Netherlands.
Rook, A. J., C. A. Huckle, and P. D. Penning. 1994. Effects of sward height and concentrate supplementation on the ingestive behavior of spring-calving dairy-cows grazing grass clover swards. Appl. Anim. Behav. Sci. 40:101-112.

Schmidt, G. H. 1960. Effect of milking intervals on the rate of milk and fat secretion. J. Dairy Sci. 43:213-219.

Speicher, J. A., H. A. Tucker, R. W. Ashley, E. P. Stanisiewski, J. F. Boucher, and C. J. Sniffen. 1994. Production responses of cows to recombinantly derived bovine somatotropin and to frequency of milking. J. Dairy Sci. 77:2509-2517.

Stockdale, C. R. 2006. Influence of milking frequency on the productivity of dairy cows. Aust. J. Exp. Agric. 46:965-974.

Wilde, C. J., C. V. P. Addey, L. M. Boddy, and M. Peaker. 1995. Autocrine regulation of milk secretion by a protein in milk. Biochem. J. 305:51-58.

Woolford, M. W., R. W. Claycomb, J. Jago, K. Davis, I. Ohnstad, R. Wieliczko, P. J. A. Copeman, and K. Bright. 2004. Automatic dairy farming in New Zealand using extensive grazing systems. Pages 280-285 in conf. proc. Automatic Milking: A Better Understanding, Lelystad, Netherlands. Wageningen Academic Publishers, Wageningen, the Netherlands. 